\title{
Evidence for greater oxygen decline rates in the coastal ocean than in the open ocean
}

\author{
D. Gilbert ${ }^{1}$, N. N. Rabalais ${ }^{2}$, R. J. Díaz ${ }^{3}$, and J. Zhang ${ }^{4}$ \\ ${ }^{1}$ Institut Maurice-Lamontagne, Pêches et Océans Canada, 850 Route de la mer, Mont-Joli, Québec, G5H 3Z4, Canada \\ ${ }^{2}$ Louisiana Universities Marine Consortium, 8124 Highway 56, Chauvin, LA 70344, USA \\ ${ }^{3}$ Virginia Institute of Marine Science, College of William and Mary, Gloucester Point, VA 23062, USA \\ ${ }^{4}$ State Key Laboratory of Estuarine and Coastal Research, East China Normal University, 3663 Zhongshan Road North, \\ Putuo District, Shanghai, 200062, China
}

Received: 1 September 2009 - Published in Biogeosciences Discuss.: 18 September 2009

Revised: 5 July 2010 - Accepted: 10 July 2010 - Published: 26 July 2010

\begin{abstract}
In the global ocean, the number of reported hypoxic sites (oxygen $<30 \%$ saturation) is on the rise both near the coast and in the open ocean. But unfortunately, most of the papers on hypoxia only present oxygen data from one or two years, so that we often lack a long-term perspective on whether oxygen levels at these locations are decreasing, steady or increasing. Consequently, we cannot rule out the possibility that many of the newly reported hypoxic areas were hypoxic in the past, and that the increasing number of hypoxic areas partly reflects increased research and monitoring efforts. Here we address this shortcoming by computing oxygen concentration trends in the global ocean from published time series and from time series that we calculated using a global oxygen database. Our calculations reveal that median oxygen decline rates are more severe in a $30 \mathrm{~km}$ band near the coast than in the open ocean $(>100 \mathrm{~km}$ from the coast). Percentages of oxygen time series with negative oxygen trends are also greater in the coastal ocean than in the open ocean. Finally, a significant difference between median published oxygen trends and median trends calculated from raw oxygen data suggests the existence of a publication bias in favor of negative trends in the open ocean.
\end{abstract}

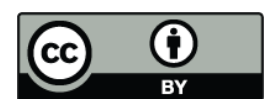

Correspondence to: D. Gilbert (denis.gilbert@dfo-mpo.gc.ca)

\section{Introduction}

Several studies suggest that oxygen levels are generally decreasing both in the coastal ocean (Díaz and Rosenberg, 2008) and in the deep ocean (Keeling and Garcia, 2002). This is cause for concern as lower concentrations of dissolved oxygen (DO) have adverse effects on marine life, ranging from reduced growth and reproductive capacity to habitat avoidance and ultimately death. At some coastal sites, eutrophication (Nixon, 1995) from nearby rivers appears to be the main cause of hypoxia (Kemp et al., 2005; Rabalais et al., 2002). But at other sites on the continental shelf and in the deep ocean, changes in ocean circulation (Gilbert et al., 2005; Monteiro et al., 2006) or in winter ventilation (Whitney et al., 2007) also play a role in lowering oxygen concentrations.

To make things worse, biogeochemistry models embedded within ocean global circulation models (OGCM) generally predict that oxygen concentrations in the ocean will decrease in the coming decades as a consequence of global warming (e.g., Frölisher et al., 2009). There are early indications that this may already be detectable (Stramma et al., 2008; Johnson and Gruber, 2007; Stramma et al., 2010), but interdecadal changes in ocean circulation could have played a role in these trends (Frölisher et al., 2009).

According to Díaz and Rosenberg (2008), the number of hypoxic sites around the world reported in the scientific literature has increased about an order of magnitude (40 to 400 sites) from the 1960s to the present. This seems to indicate that hypoxia is becoming much more widespread and more severe relative to the historical literature. But we need to be careful in order to interpret this finding correctly. The fact that more papers dealing with coastal hypoxia started

Published by Copernicus Publications on behalf of the European Geosciences Union. 
to appear since the 1990s could also indicate that scientists have devoted more efforts to detecting and reporting hypoxia. Do the new reports of hypoxic conditions reflect a truly widespread phenomenon, or do they reflect a greater tendency for scientists to report low oxygen conditions, because of the associated adverse ecological implications, than to report stable or increasing oxygen levels?

In this paper, we compile global oxygen trend statistics from a coastal band ( 0 to $30 \mathrm{~km}$ from shoreline), from a transition band (30 to $100 \mathrm{~km}$ from shoreline) and from the open ocean ( $>100 \mathrm{~km}$ from shoreline). In each distance category, the mean trends, median trends and percentage of negative trends are calculated from oxygen time series published in refereed journals, and from oxygen time series obtained from a global oxygen database. In Sect. 2, we provide the details of our search for papers containing plots of oxygen time series spanning at least one decade, and how we determined trends from these time series. We also describe the methods used to merge various public databases in order to construct oxygen time series at fixed stations and compute trends from them. In Sect. 3, we present maps, a histogram, and statistics of oxygen trends based on the scientific literature, and based on our analyses from raw data at fixed stations in the global ocean. In Sect. 4, we discuss the implications of our findings, and we present the main conclusions in Sect. 5.

\section{Materials and methods}

\subsection{Published oxygen time series}

Because interannual oxygen variability is important in most marine systems (Garcia et al., 2005), we required that oxygen time series have a duration of at least 10 years. While this selection criterion allows us to minimize noise due to variability with time scales of up to a few years, it does not eliminate noise in trend estimates caused by oxygen variations with decadal and longer time scales that are beyond the resolution of our time series. Being concerned with the large diurnal oxygen cycles that are characteristic of shallow estuaries (e.g., $2 \mathrm{~m}$ deep coastal lagoon estuary, Tyler et al., 2009), we also limited our attention to sites where the bottom was at least $10 \mathrm{~m}$ deep, because time of sampling during the day influences oxygen measurements and would complicate statistical analyses in shallower marine systems. Finally, we restricted our attention to oxygen data determined by chemical titration. The titration method originally proposed by Winkler (1888) suffers from slight inaccuracies (Wong and Li, 2009) and has evolved over time (e.g., Carpenter, 1965; Jones et al., 1992), but these changes in titration methods have negligible effects on our trend estimates. We excluded data from electronic oxygen sensors from our analyses. For some locations, this severely hampers data availability, as more and more people use polarographic or optical sensors to measure oxygen. These oxygen probes
Table 1. Conversion factors to transform oxygen concentrations from the original reported units to $\mu \mathrm{mol} \mathrm{L} \mathrm{L}^{-1}$.

\begin{tabular}{ll}
\hline Original units & Conversion factor \\
\hline $\mathrm{mg} \mathrm{L}^{-1}$ & 31.231 \\
$\mathrm{~mL} \mathrm{~L}^{-1}$ & 44.615 \\
$\mathrm{~cm}^{3} \mathrm{dm}^{-3}$ & 44.615 \\
$\mathrm{mg} \mathrm{atom} \mathrm{m}^{-3}$ & 1 \\
$\mu \mathrm{mol} \mathrm{kg}$ & $\sim 1$ \\
\hline
\end{tabular}

can provide excellent data when they are routinely calibrated against Winkler titrations. But in many laboratories, the lack of regular sensor calibration can lead to inaccurate or suspicious data. The United States National Oceanographic Data Center (US NODC) took the decision to only use oxygen data believed to be obtained by chemical titration methods in their production of the climatological World Ocean Atlas 2005 (Garcia et al., 2006), and we followed their example by erring on the side of caution for this global ocean data analysis. With respect to the calculation of trends, only using Winkler titrations offers an additional benefit. It minimizes the possibility of introducing artificial jumps in the time series arising from a change in measurement method.

We restricted our literature search with the ASFA (Aquatic Sciences and Fisheries Abstracts) and SCOPUS bibliography databases to papers with publication dates of 1985 and later. Some time series were eliminated from our analyses because they did not contain precise depth information (e.g., Lysiak-Pastuszak et al., 2004) for their measurements. In other cases, the individual data points were so cluttered that digitization was virtually impossible to do in a reliable way. One such cluttered time series, from Justić et al. (1987), was nevertheless included in our study by using their trend estimate for the bottom waters of the northern Adriatic Sea and converting the original concentration units of $\mathrm{cm}^{3} \mathrm{dm}^{-3}$ to $\mu \mathrm{mol} \mathrm{L}{ }^{-1}$ (Table 1). Other oxygen time series with original concentration units other than $\mu \mathrm{mol} \mathrm{L}{ }^{-1}$ were also converted using the factors given in Table 1.

For refereed journal papers in which near-bottom oxygen values were plotted, it was sometimes necessary to make an educated guess about the depth of the time series based on local bathymetry (Conley et al., 2007; Peng et al., 2009). In other cases, we had to estimate the climatological depth of isopycnal surfaces (Kang et al., 2004; Konovalov and Murray, 2001; Nakanowatari et al., 2007). In one instance (Lin et al., 2005), we had to correct the originally published oxygen time series (with concentrations over $600 \mu \mathrm{mol} \mathrm{L}^{-1}$ ) by dividing the published concentrations by a factor of two. The origin of this error in data reporting remains unclear, but one possibility is that the authors reported atomic $(\mathrm{O})$ rather than molecular $\left(\mathrm{O}_{2}\right)$ oxygen concentrations. 


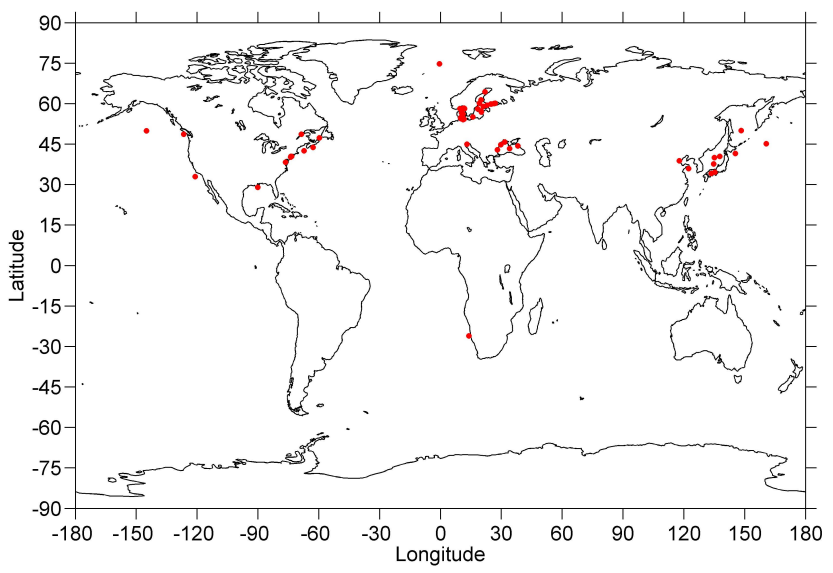

Fig. 1. Station locations (red dots) of digitized oxygen concentration time series from refereed journal publications.

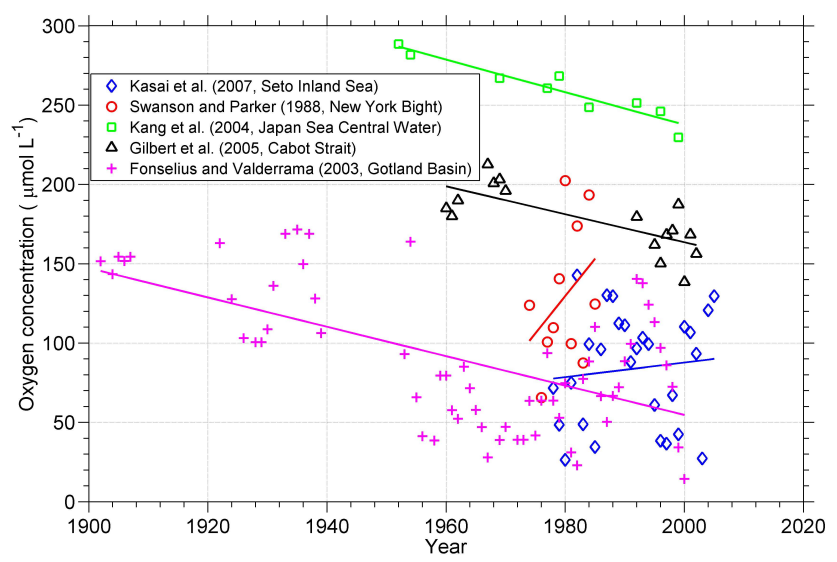

Fig. 2. Examples of digitized oxygen time series from refereed journal papers and our fitted linear trends. The Gotland Basin time series is from $100 \mathrm{~m}$ depth.

Figure 1 shows the locations of the published oxygen time series used in our study, and a few examples of digitized oxygen time series are plotted in Fig. 2. The regions of the Kattegat, Baltic Sea and Black Sea represent our most abundant sources of published oxygen data. Other areas with reasonable geographic coverage include the East/Japan Sea and coastal waters around Japan and North America. Unfortunately, a single time series from the southern hemisphere satisfied our selection criteria (Monteiro et al., 2008). In some cases, negative oxygen values indicate the presence of $\mathrm{H}_{2} \mathrm{~S}$ which represents a chemical oxygen debt and was converted to oxygen concentration after multiplying the $\mathrm{H}_{2} \mathrm{~S}$ concentration by -2 . Published oxygen time series with negative values due to the $\mathrm{H}_{2} \mathrm{~S}$ correction are indicated by an asterisk in Table 2.

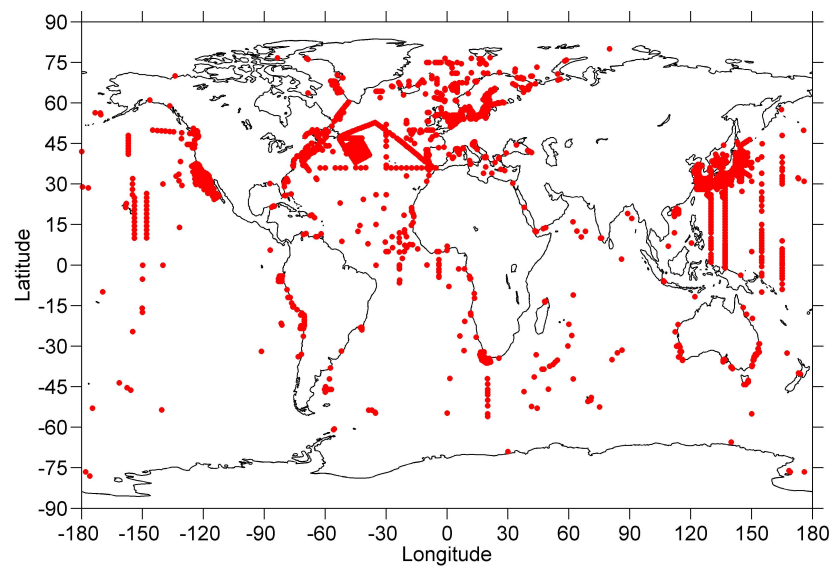

Fig. 3. Station locations (red dots) of oxygen concentration time series calculated from a global oxygen database.

\subsection{Oxygen time series from a global dataset}

Most of the oxygen data used in this paper come from a series of queries made in September 2008 at the National Oceanographic Data Center (NODC) of the United States. While the US NODC database is global in scope, it is never entirely up-to-date, often missing substantial data from the most recent years. Our second most important source of oxygen data is the ICES (International Council for the Exploration of the Sea) database, from which we also ran a series of queries in September 2008. To this, we added two Canadian databases: the national Biochem database from ISDM (Integrated Science Data Management, Dept. of Fisheries and Oceans, Ottawa, Ontario, Canada) and a northeast Pacific and Arctic database held at the Institute of Ocean Sciences (Sidney, BC, Canada). Finally, we obtained oxygen data from the CARIACO (Carbon Retention In A Colored Ocean) Project database (e.g., Müller-Karger et al., 2001). Since a significant proportion of the above oxygen data can be present in more than one database, we had to eliminate all duplicate records based on metadata information on the latitude, longitude, date and time (UTC) of the measurements.

Based on prior knowledge of long-term ocean monitoring programs, and on visual inspection of plots of oxygen data distribution in space and time, we selected 2132 fixed stations (Fig. 3) for the calculation of oxygen time series from raw oxygen data. For each "fixed" station, we determined the latitude and longitude coordinates of the center and allowed a data search radius of $10 \mathrm{~km}$. Then for each year, we calculated mean oxygen values at the depths of $0 \mathrm{~m}(0-2 \mathrm{~m})$, $10 \pm 1 \mathrm{~m}, 20 \pm 2.5 \mathrm{~m}, 50 \pm 5 \mathrm{~m}, 75 \pm 5 \mathrm{~m}, 100 \pm 5 \mathrm{~m}, 150 \pm 10 \mathrm{~m}$, $200 \pm 10 \mathrm{~m}, 250 \pm 10 \mathrm{~m}$ and $300 \pm 10 \mathrm{~m}$. To avoid variability in the oxygen time series associated with seasonal cycles, our analyses were limited to the summer months of July, August and September from the sea surface to $75 \mathrm{~m}$ depth. At depths of $100 \mathrm{~m}$ and greater, where the seasonal cycles are weaker, 


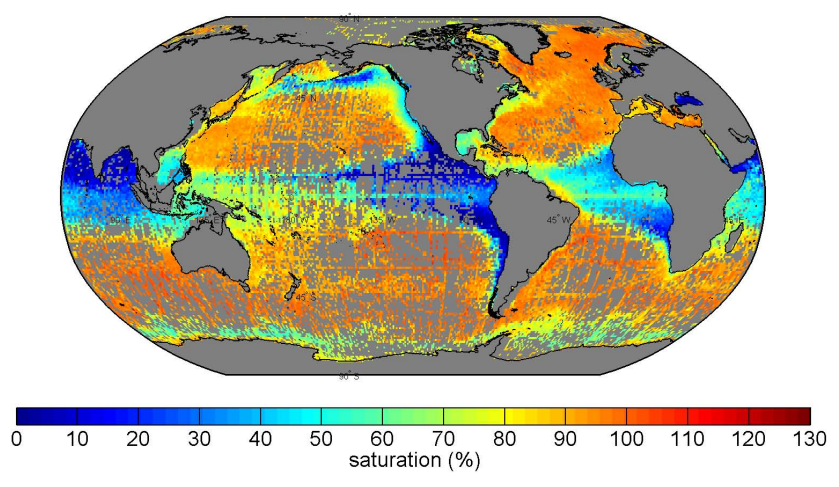

Fig. 4. Oxygen saturation percentage at $150 \mathrm{~m}$ depth, averaged over $1^{\circ}$ of latitude $\times 1^{\circ}$ of longitude polygons, based on the global oxygen database used in this study. No interpolation was performed; the grey areas indicate absence of data.

we used all available oxygen data from the twelve months of the year.

For the calculation of oxygen trends in a given time period (e.g., 1951-2000), we imposed a criterion of 30\% overall data availability and requested at least one year with data in both halves of the time series. For example, for 25-year time periods, we required at least 8 years with oxygen data. In addition, for the 1951-1975 period, we required at least one year with data before and after the middle year of 1963 . Similarly, for the 1976-2000 period, we required at least one year with data before and after the middle year of 1988. At some stations, oxygen concentrations can be very close to or equal to zero at certain depths over most of the 25-year period under consideration. In such cases, unless there is accompanying $\mathrm{H}_{2} \mathrm{~S}$ data that can be converted to negative oxygen concentrations, the oxygen trend could be meaningless. There exist some locations where $\mathrm{H}_{2} \mathrm{~S}$ data have been collected over many years (e.g., Fonselius and Valderrama, 2003; Konovalov and Murray, 2001), but this is not always the case. To ensure uniformity in our results, we therefore decided to eliminate raw data time series for which the median oxygen concentration was less than $10 \mu \mathrm{mol} \mathrm{L}{ }^{-1}$. Locations affected by this decision include the deep basins of the Baltic Sea, central Black Sea, Saanich Inlet, Cariaco Basin, and stations located in oxygen minimum zones off Peru, Chile, and India (Fig. 4).

\subsection{Grouping of trends based on distance from the coast}

Due to the effect of Earth's rotation, river plumes generally veer to the right (left) of river mouths in the Northern (Southern) Hemisphere, and then tend to flow parallel to the coastline within about one internal Rossby radius of deformation (Gill, 1982). We take $30 \mathrm{~km}$ as a representative value of one internal Rossby radius of deformation between $20^{\circ}$ and $60^{\circ}$ of latitude (Chelton et al., 1998). Based on ocean physics, we expect that most of the impacts of human-induced eutrophication should be felt within this coastal band of $30 \mathrm{~km}$ width; albeit, there are exceptions such as the Gulf of Mexico hypoxic zone associated with the Mississippi River plume that extends farther offshore (Rabalais et al., 2007).

The internal Rossby radius of deformation varies with seasonal stratification strength, but it depends mostly on latitude, with typical values of roughly $10 \mathrm{~km}$ at $60^{\circ}, 20 \mathrm{~km}$ at $45^{\circ}$, $40 \mathrm{~km}$ at $30^{\circ}$ and $80 \mathrm{~km}$ at $15^{\circ}$ (Chelton et al., 1998). Given these values, we arbitrarily take $100 \mathrm{~km}$ as a representative distance beyond which a parcel of water is no longer under the direct influence of nutrient-rich, buoyant river plumes and coastal currents. We shall refer to this distance category ( $>100 \mathrm{~km}$ from the coast) as the open ocean. Finally, between the coastal band $(0-30 \mathrm{~km})$ and the open ocean, we define a transition zone with distances from the shoreline between $30 \mathrm{~km}$ and $100 \mathrm{~km}$.

We evaluated distance from the coast for each station by using GSHHS (Global Self-consistent, Hierarchical, Highresolution Shoreline) shapefiles version 1.3 (Wessel and Smith, 1996), together with the functions $d e g 2 \mathrm{~km}$ and distance from the Matlab mapping toolbox version 2.7.2. The GSHHS shoreline exists in five spatial resolutions (crude, low, intermediate, high and full). We used the intermediate spatial resolution, which allowed us to determine distance from a fixed station to the shoreline with an estimated accuracy of about $1 \mathrm{~km}$ at a reasonable computing cost.

\subsection{Statistical methods}

For most of the published oxygen time series listed in Table 2, we produced a PNG (Portable Network Graphics) file displaying the time series, which we digitized. From the digitized data, we averaged the data from individual years to produce time series of annual mean oxygen concentration. Linear trends were then estimated from the annuallyaveraged oxygen time series. This method differs from the way some authors computed trends in their original papers. For example, some authors performed linear regressions using all individual oxygen measurements. We prefer averaging the data annually as a first pre-processing step because this avoids giving too much weight to data-rich years in the least-squares fits. However, for the Justić et al. (1987) time series, we were unable to perform a satisfactory digitization of the oxygen data, and we used their own trend estimate in Table 2. For the Bograd et al. (2008) paper, we also had to use their published trends in our Table 2 because the oxygen time series from the entire CalCOFI region were not plotted in their paper. For the six depth levels of their study, they only plotted the oxygen time series from the stations with the most pronounced negative trends.

As the main focus of this paper was to compile global statistics on oxygen trends, we did not attempt to determine the statistical significance of any individual trend. Two-sided confidence intervals for the proportions of negative trends 
Table 2. List of refereed journal publications from which we obtained oxygen trends, or from which we digitized oxygen time series and then calculated trends. We could not calculate mean DO for two papers in which the oxygen time series were plotted as anomalies. Time series with negative oxygen values (due to the presence of $\mathrm{H}_{2} \mathrm{~S}$ ) are indicated with an asterisk in the mean DO column. Distances are relative to the nearest shoreline.

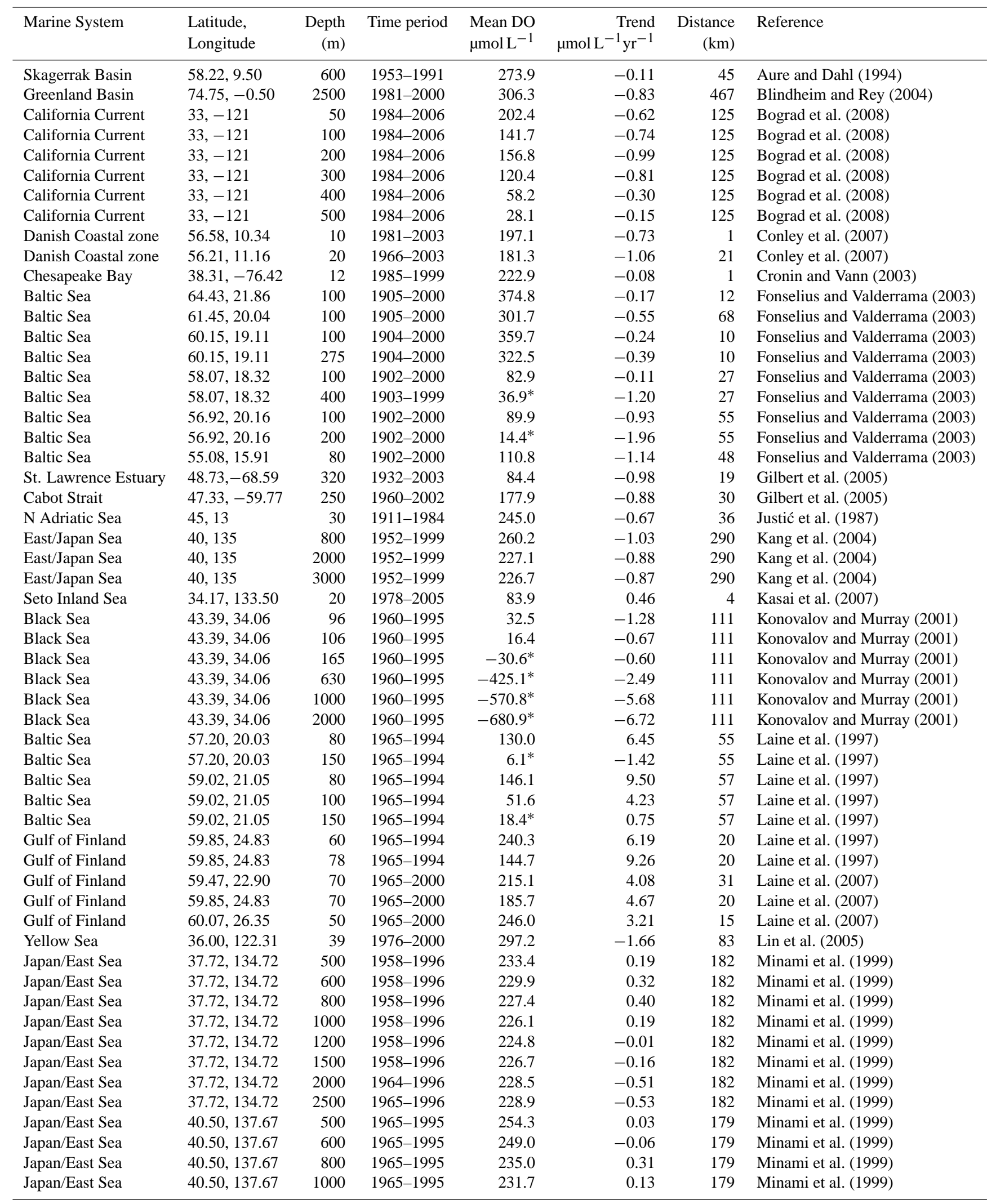


Table 2. Continued.

\begin{tabular}{|c|c|c|c|c|c|c|c|}
\hline Marine System & $\begin{array}{l}\text { Latitude, } \\
\text { Longitude }\end{array}$ & $\begin{array}{r}\text { Depth } \\
(\mathrm{m})\end{array}$ & Time period & $\begin{array}{l}\text { Mean DO } \\
\mu \mathrm{mol} \mathrm{L}\end{array}$ & $\begin{array}{r}\text { Trend } \\
\mu \mathrm{mol} \mathrm{L}^{-1} \mathrm{yr}^{-1}\end{array}$ & $\begin{array}{r}\text { Distance } \\
(\mathrm{km})\end{array}$ & Reference \\
\hline Japan/East Sea & $40.50,137.67$ & 1200 & $1965-1995$ & 229.1 & 0.01 & 179 & Minami et al. (1999) \\
\hline Japan/East Sea & $40.50,137.67$ & 1500 & 1965-1995 & 229.0 & -0.52 & 179 & Minami et al. (1999) \\
\hline Japan/East Sea & $40.50,137.67$ & 2000 & 1965-1995 & 231.6 & -0.64 & 179 & Minami et al. (1999) \\
\hline Japan/East Sea & $40.50,137.67$ & 2500 & $1965-1995$ & 235.0 & -0.71 & 179 & Minami et al. (1999) \\
\hline Benguela Current & $-26.00,14.00$ & 100 & 1994-2003 & 65.4 & -2.48 & 87 & Monteiro et al. (2008) \\
\hline Sea of Okhotsk & $50.06,148.27$ & 500 & $1960-2000$ & anomalies & -0.54 & 291 & Nakanowatari et al. (2007) \\
\hline Oyashio & $41.55,145.36$ & 400 & $1960-2000$ & anomalies & -0.57 & 161 & Nakanowatari et al. (2007) \\
\hline Subarctic Current & $45.17,160.56$ & 300 & $1963-1998$ & anomalies & -0.23 & 628 & Nakanowatari et al. (2007) \\
\hline Gullmar Fjord & $58.32,11.55$ & 119 & 1961-1996 & 140.0 & -1.69 & 1 & Nordberg et al. (2000) \\
\hline Tianjin coastal sea & $38.85,117.75$ & 10 & 1996-2006 & 234.7 & -1.97 & 10 & Peng et al. (2009) \\
\hline Scotian Shelf & $43.84,-62.86$ & 150 & 1961-1999 & anomalies & -1.06 & 87 & Petrie and Yeats (2000) \\
\hline Gulf of Maine & $42.53,-67.25$ & 150 & $1951-1988$ & anomalies & 0.45 & 138 & Petrie and Yeats (2000) \\
\hline Gulf of Finland & $59.90,25.04$ & 65 & $1966-2000$ & 166.1 & 2.09 & 17 & Pitkänen et al. (2001) \\
\hline Gulf of Finland & $60.17,26.98$ & 55 & $1971-2000$ & 261.6 & -0.91 & 8 & Pitkänen et al. (2001) \\
\hline Baltic Sea (Gotland Basin) & $57.32,20.05$ & 200 & $1990-2003$ & $-143.2^{*}$ & 2.85 & 65 & Pohl and Hennings (2005) \\
\hline West coast of Sweden & $58.37,11.37$ & 25 & $1962-1984$ & 198.5 & -3.51 & 0 & Rosenberg (1990) \\
\hline West coast of Sweden & $58.36,11.43$ & 25 & $1963-1984$ & 197.3 & -2.49 & 0 & Rosenberg (1990) \\
\hline West coast of Sweden & $58.32,11.37$ & 33 & $1964-1983$ & 208.8 & -3.25 & 0 & Rosenberg (1990) \\
\hline West coast of Sweden & $58.40,11.63$ & 62 & $1968-1984$ & 71.7 & -7.23 & 0 & Rosenberg (1990) \\
\hline West coast of Sweden & $58.25,11.43$ & 55 & $1952-1985$ & 186.0 & -3.66 & 1 & Rosenberg (1990) \\
\hline West coast of Sweden & $58.23,11.58$ & 40 & $1951-1983$ & $-21.5^{*}$ & -1.30 & 0 & Rosenberg (1990) \\
\hline West coast of Sweden & $58.29,11.68$ & 55 & 1951-1984 & $-16.3^{*}$ & -1.41 & 0 & Rosenberg (1990) \\
\hline West coast of Sweden & $58.19,11.85$ & 23 & $1952-1984$ & 126.1 & -3.97 & 0 & Rosenberg (1990) \\
\hline New York Bight & $40.38,-73.74$ & 33 & $1974-1985$ & 129.3 & 4.69 & 20 & Swanson and Parker (1988) \\
\hline New York Bight & $40.21,-73.94$ & 22 & $1974-1985$ & 136.6 & 2.33 & 5 & Swanson and Parker (1988) \\
\hline Louisiana Shelf & $28.99,-90.07$ & 27 & 1980-1995 & 94.3 & -3.75 & 16 & Turner et al. (2005) \\
\hline Southwestern Baltic Sea & $54.80,9.96$ & 25 & 1979-1993 & $33.9^{*}$ & -1.15 & 2 & Weichart et al. (1994) \\
\hline Southwestern Baltic Sea & $54.59,10.47$ & 25 & $1976-1993$ & 101.5 & -6.08 & 19 & Weichart et al. (1994) \\
\hline Southwestern Baltic Sea & $54.48,9.97$ & 25 & $1976-1993$ & $23.1^{*}$ & -0.11 & 1 & Weichart et al. (1994) \\
\hline Southwestern Baltic Sea & $54.12,11.09$ & 25 & $1976-1993$ & $19.6^{*}$ & -1.50 & 7 & Weichart et al. (1994) \\
\hline Southwestern Baltic Sea & $54.56,11.35$ & 25 & $1979-1993$ & $38.0^{*}$ & 0.66 & 9 & Weichart et al. (1994) \\
\hline Southwestern Baltic Sea & $54.32,11.57$ & 50 & $1979-1993$ & $39.0^{*}$ & 0.59 & 19 & Weichart et al. (1994) \\
\hline Gulf of Alaska & $50.00,-145.00$ & 140 & $1956-2005$ & 211.3 & -0.55 & 912 & Whitney et al. (2007) \\
\hline Gulf of Alaska & $50.00,-145.00$ & 168 & $1956-2005$ & 167.4 & -0.79 & 912 & Whitney et al. (2007) \\
\hline Gulf of Alaska & $50.00,-145.00$ & 278 & $1956-2005$ & 84.5 & -0.62 & 912 & Whitney et al. (2007) \\
\hline Gulf of Alaska & $50.00,-145.00$ & 370 & $1956-2005$ & 57.9 & -0.27 & 912 & Whitney et al. (2007) \\
\hline Gulf of Alaska & $48.66,-126.67$ & 168 & $1987-2005$ & 88.0 & -1.10 & 71 & Whitney et al. (2007) \\
\hline Long Island Sound & $40.51,-73.48$ & 27 & $1946-2006$ & 139.7 & -1.43 & 10 & Wilson et al. (2008) \\
\hline Long Island Sound & $40.47,-73.82$ & 21 & $1985-2000$ & 115.1 & 2.68 & 12 & Wilson et al. (2008) \\
\hline Black Sea & $44.40,38.08$ & 70 & 1984-2004 & 235.5 & -2.27 & 9 & Yakushev et al. (2006) \\
\hline Osaka Bay & $34.60,135.29$ & 18 & $1972-2002$ & 183.2 & 0.42 & 11 & Yasuhara et al. (2007) \\
\hline western Black Sea & $42.90,28.00$ & 20 & $1961-1998$ & 188.3 & -2.14 & 8 & Yunev et al. (2007) \\
\hline western Black Sea & $45.84,31.65$ & 20 & $1960-1998$ & 183.7 & -1.65 & 43 & Yunev et al. (2007) \\
\hline western Black Sea & $44.80,29.72$ & 20 & 1960-1998 & 180.9 & -1.23 & 10 & Yunev et al. (2007) \\
\hline
\end{tabular}

were obtained using the binofit function from the Matlab statistics toolbox. Confidence intervals for differences in proportions were based on the method proposed by Fagan (1999). We tested our samples of oxygen trends for normality using the Kolmogorov-Smirnov test. As this test failed for many of the trend samples, we do not present confidence intervals for the mean trends in Tables 3 to 8, and we could not use two-sample t-tests to compare mean trends from various situations or geographical settings. Equality of medians was verified with the Mann-Whitney U-test, using the ranksum function from the Matlab statistics toolbox. We always give 95\% confidence intervals for parametric estimates, and hypothesis testing is done at the $\alpha=0.05$ significance level. 


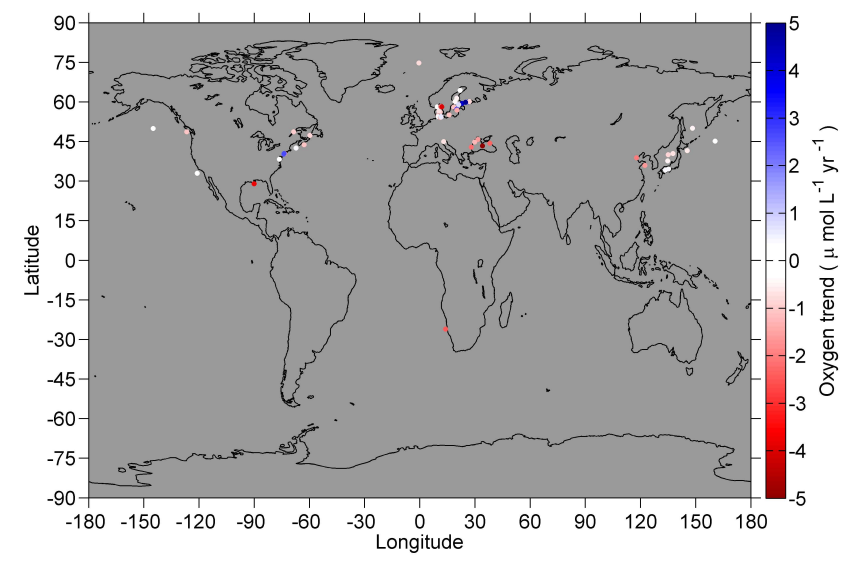

Fig. 5. Map of oxygen trends from refereed journal publications (Table 2).

\section{Results}

\subsection{Published time series}

Table 2 gives the linear trend of each published oxygen time series, together with its latitude, longitude, depth, time period over which the trend was estimated, mean DO, distance from the coast, and journal reference. An overall summary of these trends estimated over the entire length of the time series is given in Table 3, based on distance from the coast. In the $0-30 \mathrm{~km}$ coastal band, we find a median oxygen trend of $-0.98 \mu \mathrm{mol} \mathrm{L}^{-1} \mathrm{yr}^{-1}$. The median oxygen trends in the other two distance bands are also negative, but less so than in the coastal band. A global map of oxygen trends determined from published time series is shown in Fig. 5. To interpret this map correctly, it is necessary to recall that at certain fixed stations (e.g., station P in Whitney et al., 2007), we have trend estimates from more than one depth level (Table 2) and these are overlain on top of each other. This map shows the general prevalence of negative published oxygen trends, but also highlights a great deal of variability in trend estimates. A histogram of published trends separated into two time series length categories ( $\leq 33$ years or $>33$ years) is presented in Fig. 6. It shows a greater prevalence of trends with large absolute values for the shorter time series. The standard deviation of the published trends is larger for the group with shorter time series $\left(3.16 \mu \mathrm{mol} \mathrm{L}^{-1} \mathrm{yr}^{-1}\right)$ than for the group with longer time series $\left(1.84 \mu \mathrm{mol} \mathrm{L}^{-1} \mathrm{yr}^{-1}\right)$.

For the purpose of comparison with trends calculated from raw data over the 1976-2000 period, we also present summary statistics of published trends for the 1976-2000 period (Table 4). As we did for the oxygen time series calculated from raw data, the individual 1976-2000 published trends were computed by requiring at least eight separate years with oxygen data over the 1976-2000 period and requiring at least one year with data before and after the middle year of 1988 . One of the interesting differences between Tables 3 and 4 is

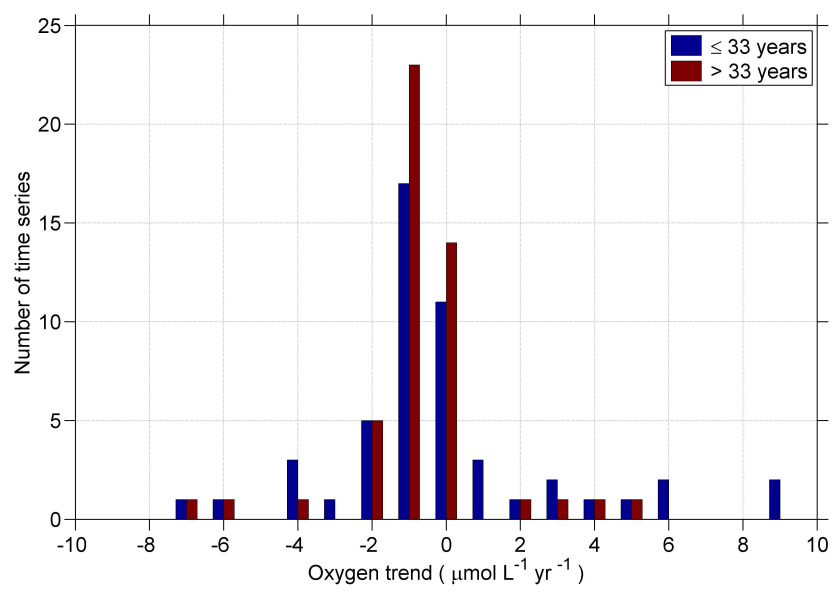

Fig. 6. Histogram of oxygen concentration trends calculated from published oxygen time series (Table 2) shorter than or equal to 33 years (blue, $\mathrm{N}=51$ ) or longer than 33 years (red, $\mathrm{N}=49$ ).

that the median trends, although still negative, are closer to zero during the 1976-2000 period for the three categories of distance from the coast. The percentages of negative trends for the 1976-2000 period (Table 4) also diminished relative to those obtained over the entire length of the published time series (Table 3).

\subsection{Calculated time series}

Trend statistics for the 1976-2000 time period are presented in Tables 5 to 7 . In the $0-30 \mathrm{~km}$ coastal band, the mean oxygen trend and the median oxygen trend are negative at nine of the ten standard depths (Table 5). The percentage of oxygen time series with negative trends is greater than $50 \%$ at eight of the ten depths.

In the $30-100 \mathrm{~km}$ transition band between the coastal zone and the open ocean, the mean oxygen trend and the median trend are negative at all depths but $75 \mathrm{~m}$ (Table 6). Likewise, the percentage of oxygen time series with negative trends is greater than $50 \%$ at all depths but $75 \mathrm{~m}$.

Finally, for open ocean stations located at distances greater than $100 \mathrm{~km}$ from the shoreline, the mean oxygen trend is negative at nine depths (Table 7). The percentage of oxygen time series with negative trends is greater than $50 \%$ at six of the ten depths, and the median trend is negative at the same six depths out of ten.

Depth-averaged (0-300 m) trend statistics for the 19762000 period were also obtained (Table 8 ) by combining trend estimates from the $0,50,100,150,200,250$ and $300 \mathrm{~m}$ depth levels for the three categories of distance from the coast (Tables 5 to 7 ). The mean oxygen trend over the 0 to $300 \mathrm{~m}$ depth range is equal to $-0.35 \mu \mathrm{mol} \mathrm{L} \mathrm{Lr}^{-1} \mathrm{yr}^{-1}$ in the coastal ocean, $-0.19 \mu \mathrm{mol} \mathrm{L}^{-1} \mathrm{yr}^{-1}$ in the $30-100 \mathrm{~km}$ transition band, and $-0.09 \mu \mathrm{mol} \mathrm{L}^{-1} \mathrm{yr}^{-1}$ in the open ocean (Table 8).

The median oxygen trend in the coastal ocean $(-0.28$ $\mu \mathrm{mol} \mathrm{L} \mathrm{Lr}^{-1} \mathrm{yr}^{-1}$ ) is significantly different from the median 
Table 3. Oxygen trend statistics $\left(\mu \mathrm{mol} \mathrm{L}^{-1} \mathrm{yr}^{-1}\right)$ from published time series in various ranges of distances from the coast, using data from the entire time series. Abbreviations: C. I. = confidence interval; Std Dev = standard deviation; $\mathrm{N}=$ number of time series; Perc Neg $=$ Percentage of negative trends.

\begin{tabular}{lccccccl}
\hline $\begin{array}{l}\text { Distance from } \\
\text { coast }(\mathrm{km})\end{array}$ & Median & Mean & Std Dev & $\mathrm{N}$ & Perc. Neg. & $\begin{array}{l}\text { Perc. Neg. } \\
\text { 95\% C. I. }\end{array}$ & Comment \\
\hline $0-30$ & -0.98 & -0.46 & 3.09 & 41 & 70.7 & {$[54.5,83.9]$} & $\begin{array}{l}+9.26 \text { outlier } \\
\text { (Laine et al., 1997) }\end{array}$ \\
$30-100$ & -0.88 & 0.64 & 3.25 & 19 & 68.4 & {$[43.5,87.4]$} & $\begin{array}{l}+9.50 \text { outlier } \\
\text { (Laine et al., 1997) } \\
-6.72 \text { outlier } \\
\text { (Konovalov and Murray, 2001) }\end{array}$ \\
\hline $100+$ & -0.54 & -0.74 & 1.38 & 40 & 77.5 & {$[61.5,89.2]$} & \\
\hline
\end{tabular}

Table 4. Oxygen trend statistics $\left(\mu \mathrm{mol} \mathrm{L} \mathrm{L}^{-1} \mathrm{yr}^{-1}\right)$ for published time series in various ranges of distances from the coast, for the 1976-2000 period. Abbreviations: C. I. = confidence interval; Std Dev = standard deviation; $\mathrm{N}=$ number of time series; Perc Neg $=$ Percentage of negative trends.

\begin{tabular}{|c|c|c|c|c|c|c|c|}
\hline $\begin{array}{l}\text { Distance from } \\
\text { coast }(\mathrm{km})\end{array}$ & Median & Mean & Std Dev & $\mathrm{N}$ & Perc. Neg. & $\begin{array}{l}\text { Perc. Neg. } \\
\text { 95\% C.I. }\end{array}$ & Comment \\
\hline $0-30$ & -0.07 & 0.22 & 2.58 & 30 & 53.3 & {$[34.3,71.7]$} & $\begin{array}{l}\text { +7.90 outlier } \\
\text { (Laine et al., 1997) }\end{array}$ \\
\hline 30-100 & -0.25 & 1.26 & 4.25 & 15 & 53.3 & {$[26.6,78.7]$} & $\begin{array}{l}+11.8 \text { and }+8.38 \text { outliers } \\
\text { (Laine et al., 1997) }\end{array}$ \\
\hline $100+$ & -0.31 & -0.98 & 2.38 & 30 & 66.7 & {$[47.2,82.7]$} & $\begin{array}{l}-8.05 \text { and }-7.99 \text { outliers } \\
\text { (Konovalov and Murray, 2001) }\end{array}$ \\
\hline
\end{tabular}

trend in the $30-100 \mathrm{~km}$ band $(p=0.006)$ and in the open ocean $(>100 \mathrm{~km}, p<0.001)$. Likewise, the median oxygen trend in the $30-100 \mathrm{~km}$ band $\left(-0.15 \mu \mathrm{mol} \mathrm{L}^{-1} \mathrm{yr}^{-1}\right)$ differs significantly from the median trend in the open ocean $(p<0.001)$.

The percentage of negative trends between 0 and $300 \mathrm{~m}$ depth (Table 8) is significantly greater in the coastal ocean (64.2\%) than in the open ocean $(49.1 \%)$. The percentage difference is between $9.9 \%$ and $20.1 \%$ at the $95 \%$ confidence level (Fagan, 1999). The percentage of negative trends is also significantly greater in the $30-100 \mathrm{~km}$ band $(57.6 \%)$ than in the open ocean, the difference being between $4.1 \%$ and $12.9 \%$ at the $95 \%$ confidence level. However, the difference in percentage of negative oxygen trends between the coastal ocean $(0-30 \mathrm{~km})$ and the $30-100 \mathrm{~km}$ band is more subtle, with a $95 \%$ confidence interval between $0.4 \%$ and $12.6 \%$.

Comparing the summary results from published time series over the 1976-2000 period (Table 4) with the summary results obtained with time series calculated from raw data over the same time period (Table 8), we find no significant difference between published and calculated median trends for the coastal band $(0-30 \mathrm{~km})$ and for the 30-100 km band. However, the median of published trends over the 1976-2000 period from the open ocean $\left(-0.31 \mu \mathrm{mol} \mathrm{L}^{-1} \mathrm{yr}^{-1}\right)$ is significantly different from the median of trends calculated from raw oxygen data $\left(0.02 \mu \mathrm{mol} \mathrm{L}^{-1} \mathrm{yr}^{-1}\right)$. This indicates a possible inclination to more frequently publish papers with negative oxygen trends in the open ocean. Based on Fagan (1999)'s test however, none of the differences in the percentage of negative trends between Tables 4 and 8 is significant at the $\alpha=0.05$ level for the 1976-2000 period.

Oxygen trend estimates display greater variability over short time periods (e.g., 1991-2000) than over longer time periods (e.g., 1951-2000), as can be seen from the colorbar scales of trends for waters surrounding Japan (Fig. 7) and Europe (Fig. 8). Comparing oxygen trend estimates from the 25-year periods 1951-1975 and 1976-2000 in Figs. 7 and 8, we see qualitative evidence for a greater proportion of negative trends in the 1976-2000 period than in the 1951-1975 period, which we tested statistically. Changes in the estimated DO trends, either positive or negative, were compared between the two 25-year periods (1951-1975 and 19762000) using logistic regression. Data were also categorized into depth intervals (lower limits of each category being 0 , $10,20,50,75,100,150,200,250,300 \mathrm{~m})$ and distance from the coastline $(<30,30-100$, and $>100 \mathrm{~km})$. There was no multicolinearity between depth and distance from coastline (variance inflation was 1.00 for both variables). This was 

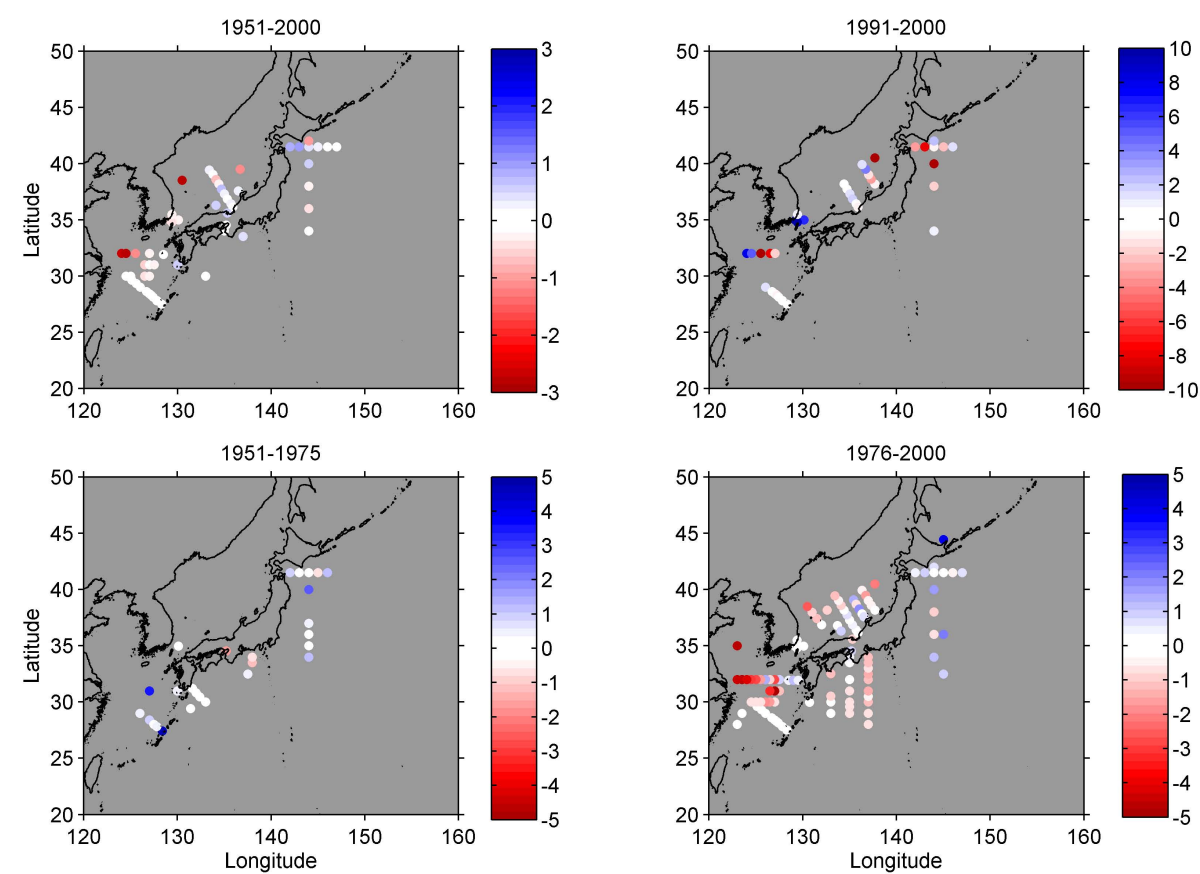

Fig. 7. Oxygen concentration trends $\left(\mu \mathrm{mol} \mathrm{L} \mathrm{L}^{-1} \mathrm{yr}^{-1}\right)$ computed from a global oxygen database at $20 \mathrm{~m}$ depth around Japan for (a) 19512000, (b) 1991-2000, (c) 1951-1975, (d) 1976-2000.
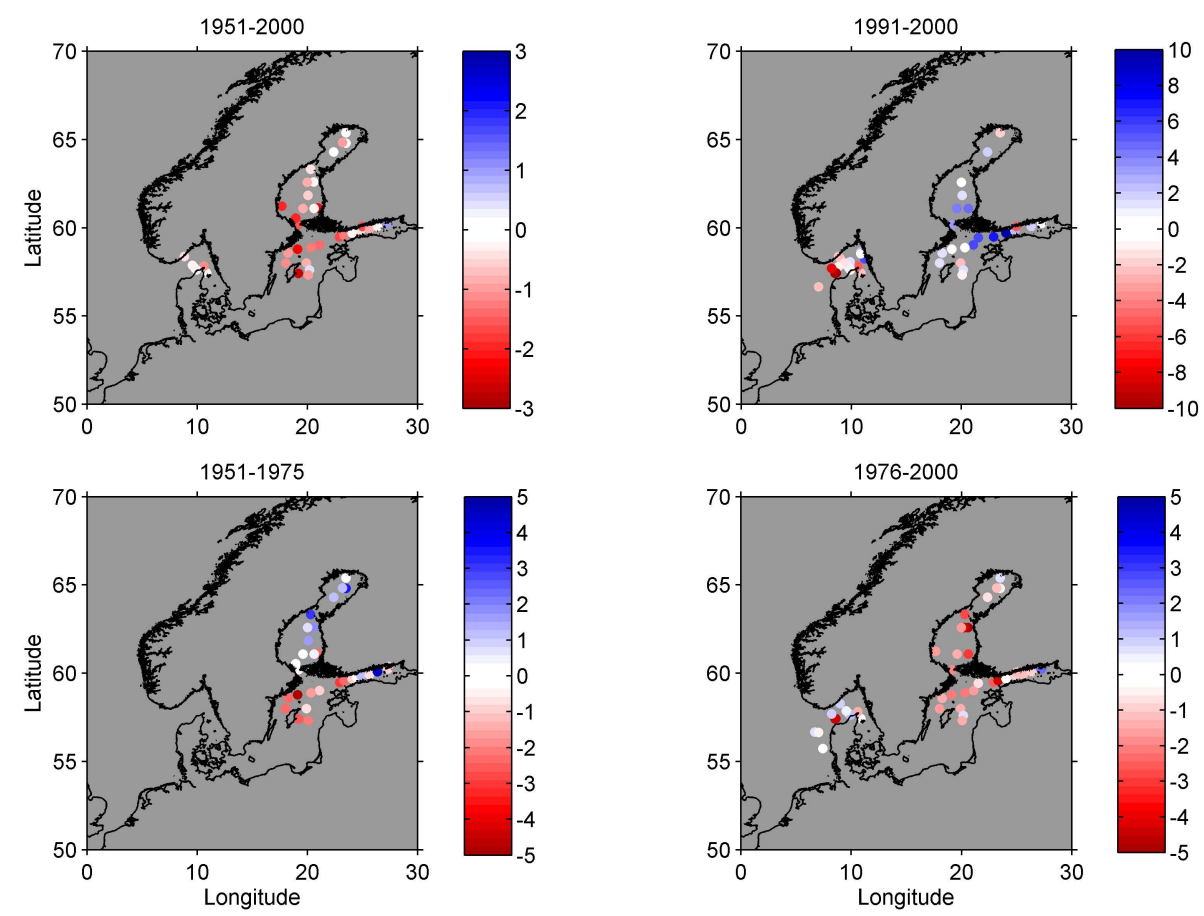

Fig. 8. Oxygen concentration trends $\left(\mu \mathrm{mol} \mathrm{L}^{-1} \mathrm{yr}^{-1}\right)$ computed from a global oxygen database at $20 \mathrm{~m}$ depth around northern Europe for (a) 1951-2000, (b) 1991-2000, (c) 1951-1975, (d) 1976-2000. 
Table 5. Oxygen trend statistics $\left(\mu \mathrm{mol} \mathrm{L}-1 \mathrm{yr}^{-1}\right.$ ) calculated from raw data in the coastal ocean, 0-30 km from the shoreline, for the 19762000 period. Abbreviations: C. I. = confidence interval; Std Dev = standard deviation; N = number of time series; Perc Neg = Percentage of negative trends. Region abbreviations: $\mathrm{BKS}=$ Baltic Sea, Kattegat and Skagerrak; $\mathrm{BC}=\mathrm{British}$ Columbia; CalCOFI = California Cooperative Oceanic Fisheries Investigations; GSL = Gulf of St. Lawrence.

\begin{tabular}{rrrcccl}
\hline Depth (m) & Median & Mean & Std Dev & N & Perc. Neg. & Regions with most time series \\
\hline 0 & -0.22 & -0.36 & 1.05 & 95 & 63.2 & BKS, CalCOFI, Japan \\
10 & -0.36 & -0.60 & 1.42 & 95 & 69.5 & BKS, CalCOFI, Japan \\
20 & -0.39 & -0.48 & 1.49 & 91 & 64.8 & BKS, CalCOFI, Japan \\
50 & -0.22 & -0.23 & 1.28 & 64 & 57.8 & BKS, CalCOFI, Japan \\
75 & -0.01 & 0.37 & 1.80 & 42 & 50.0 & BKS, CalCOFI, Japan \\
100 & -0.72 & -0.48 & 1.66 & 94 & 72.3 & BC, BKS, CalCOFI, GSL, Japan \\
150 & -0.26 & -0.34 & 1.02 & 58 & 67.2 & BC, BKS, CalCOFI, GSL, Japan \\
200 & -0.33 & -0.40 & 1.03 & 55 & 70.9 & BC, BKS, CalCOFI, GSL, Japan \\
250 & 0.15 & -0.07 & 0.94 & 33 & 42.4 & BC, BKS, CalCOFI, GSL, Japan \\
300 & -0.20 & -0.41 & 0.93 & 25 & 60.0 & CalCOFI, GSL, Japan \\
\hline
\end{tabular}

Table 6. Oxygen trend statistics $\left(\mu \mathrm{mol} \mathrm{L}{ }^{-1} \mathrm{yr}^{-1}\right.$ ) calculated from raw data in the transition band, between 30 and $100 \mathrm{~km}$ from the shoreline, for the 1976-2000 period. Abbreviations: C. I. = confidence interval; Std Dev = standard deviation; $\mathrm{N}=$ number of time series; Perc Neg $=$ Percentage of negative trends. Region abbreviations: BKS = Baltic Sea, Kattegat and Skagerrak; CalCOFI = California Cooperative Oceanic Fisheries Investigations; ECS = East China Sea; EJS = East/Japan Sea, GSL = Gulf of St. Lawrence.

\begin{tabular}{rrrcrcl}
\hline Depth $(\mathrm{m})$ & Median & Mean & Std Dev & N & Perc. Neg. & Regions with most time series \\
\hline 0 & -0.08 & -0.22 & 0.82 & 89 & 57.3 & BKS, CalCOFI, Japan \\
10 & -0.05 & -0.19 & 0.76 & 91 & 59.3 & BKS, CalCOFI, ECS, EJS, Japan \\
20 & -0.17 & -0.41 & 1.39 & 82 & 58.5 & BKS, CalCOFI, ECS, EJS, Japan \\
50 & -0.30 & -0.32 & 1.44 & 85 & 62.4 & BKS, CalCOFI, ECS, EJS, Japan \\
75 & 0.25 & 0.42 & 1.75 & 76 & 38.2 & BKS, CalCOFI, ECS, EJS, Japan \\
100 & -0.22 & -0.17 & 1.21 & 120 & 60.0 & BKS, CalCOFI, ECS, EJS, GSL, Japan \\
150 & -0.05 & -0.02 & 0.99 & 103 & 50.5 & BKS, CalCOFI, ECS, EJS, GSL, Japan \\
200 & -0.15 & -0.21 & 0.96 & 100 & 60.0 & CalCOFI, ECS, EJS, GSL, Japan \\
250 & -0.16 & -0.22 & 0.89 & 69 & 58.0 & CalCOFI, EJS, GSL, Japan \\
300 & -0.13 & -0.19 & 1.18 & 66 & 54.5 & CalCOFI, EJS, GSL, Japan \\
\hline
\end{tabular}

Table 7. Oxygen trend statistics $\left(\mu \mathrm{mol} \mathrm{L} \mathrm{L}^{-1} \mathrm{yr}^{-1}\right.$ ) calculated from raw data in the open ocean, more than $100 \mathrm{~km}$ from the shoreline, for the 1976-2000 period. Abbreviations: C. I. = confidence interval; Std Dev = standard deviation; $\mathrm{N}=$ number of time series; Perc Neg $=$ Percentage of negative trends. Region abbreviations: CalCOFI = California Cooperative Oceanic Fisheries Investigations; ECS = East China Sea; EJS = East/Japan Sea, NAtl = North Atlantic; WPac = West Pacific.

\begin{tabular}{rrrcccl}
\hline Depth $(\mathrm{m})$ & Median & Mean & Std Dev & N & Perc. Neg. & Regions with most time series \\
\hline 0 & -0.03 & -0.05 & 0.55 & 201 & 53.7 & CalCOFI, ECS, EJS, NAtl, WPac \\
10 & -0.08 & -0.19 & 0.61 & 161 & 60.2 & CalCOFI, ECS, EJS, NAtl, WPac \\
20 & -0.30 & -0.44 & 1.30 & 125 & 65.6 & CalCOFI, ECS, EJS, NAtl, WPac \\
50 & -0.11 & -0.20 & 1.03 & 190 & 58.4 & CalCOFI, ECS, EJS, Line P, NAtl, WPac \\
75 & -0.05 & -0.09 & 0.98 & 162 & 52.5 & CalCOFI, ECS, EJS, NAtl, WPac \\
100 & 0.03 & -0.08 & 1.39 & 426 & 47.9 & CalCOFI, ECS, EJS, Line P, NAtl, WPac \\
150 & 0.07 & 0.01 & 1.38 & 420 & 46.0 & CalCOFI, ECS, EJS, LineP, NAtl, WPac \\
200 & 0.04 & -0.10 & 1.47 & 412 & 47.1 & CalCOFI, EJS, Line P, NAtl, WPac \\
250 & 0.09 & -0.05 & 1.66 & 349 & 44.7 & CalCOFI, EJS, Line P, NAtl, WPac \\
300 & -0.04 & -0.23 & 1.58 & 332 & 53.3 & CalCOFI, EJS, Line P, NAtl, WPac \\
\hline
\end{tabular}


assessed using a weighted least squares regression of the predicted probabilities from the logistic regression. These statistical analyses were performed using SAS. Overall, increasing depth lowered the odds of a negative trend as did increasing distance from the coastline. But the time period had the largest effect on DO trends. Between 1951-1975 and 19762000 the odds of a negative DO trend occurring increased by over a factor of two $(p<0.001)$. Collectively, these findings are consistent with greater prevalence of coastal hypoxia in more recent years.

\section{Discussion}

The medians of published trends given in Table 3 for the $0-30 \mathrm{~km}$ band $\left(-0.98 \mu \mathrm{mol} \mathrm{L}^{-1} \mathrm{yr}^{-1}\right)$, the $30-100 \mathrm{~km}$ band $\left(-0.88 \mu \mathrm{mol} \mathrm{L}^{-1} \mathrm{yr}^{-1}\right)$, and the $100 \mathrm{~km}+$ band $(-0.54 \mu \mathrm{mol}$ $\left.\mathrm{L}^{-1} \mathrm{yr}^{-1}\right)$, are more negative than the median trends for any single depth in Tables 5, 6 and 7, respectively. This suggests that in general, scientists have a greater tendency to publish papers containing oxygen time series plots when the trend is strongly negative than when the trend is either neutral or positive. However, if we more narrowly focus on the 1976-2000 time period, the difference between the medians of published trends (Table 4) and the medians of trends calculated from raw data (Table 8 ) is only statistically significant in the open ocean $(100 \mathrm{~km}+$ band $)$.

A number of biogeochemical models embedded within ocean circulation models (Sarmiento et al., 1998; Matear et al., 2000; Bopp et al., 2002) predicted that as a consequence of global warming, oxygen levels in the ocean will decrease at a rate that is typically three to four times faster than one might expect based on changes in oxygen solubility alone (Garcia and Gordon, 1992). More recently, Frölisher et al. (2009) predicted oxygen concentration trends of -0.04 to $-0.07 \mu \mathrm{mol} \mathrm{L}^{-1} \mathrm{yr}^{-1}$ from $1990-1999$ to 2090 2099 in the upper $300 \mathrm{~m}$ of the Atlantic and Pacific Oceans. These modelled trend values are not inconsistent with the mean trend value of $-0.09 \mu \mathrm{mol} \mathrm{L}^{-1} \mathrm{yr}^{-1}$ obtained in this study for the open ocean (Table 8). However, detailed comparisons between our results and biogeochemical model predictions cannot be made with confidence due to the poor spatial coverage of the global ocean afforded by our limited set of fixed stations (Fig. 3). A greater level of observation and finer resolution models are needed to understand how and why oxygen appears to be changing at such a rapid rate at global scales (Keeling et al., 2010).

Most of the oxygen time series presented here are affected by substantial interannual to decadal oxygen variability, akin to Garcia et al. (2005) who found that oxygen time series were characterized by relatively small linear trends superimposed on large decadal-scale fluctuations. Their results indicated that overall, oxygen content had increased from the mid-1950s until the mid-1980s, and mostly decreased from the mid-1980s to the end of the 1990s. This is consistent
Table 8. Depth-averaged $(0-300 \mathrm{~m})$ oxygen trend statistics $\left(\mu \mathrm{mol} \mathrm{L}{ }^{-1} \mathrm{yr}^{-1}\right)$ for time series calculated from raw oxygen data in various ranges of distances from the coast, for the 1976-2000 period. Abbreviations: C. I. = confidence interval; Std Dev = standard deviation; $\mathrm{N}=$ number of time series; Perc Neg = Percentage of negative trends.

\begin{tabular}{lrrrrrr}
\hline $\begin{array}{l}\text { Distance } \\
\text { from } \\
\text { coast }(\mathrm{km})\end{array}$ & Median & Mean & Std Dev & N & Perc. Neg. & $\begin{array}{l}\text { Perc. Neg. } \\
95 \% \text { C. I. }\end{array}$ \\
\hline $0-30$ & -0.28 & -0.35 & 1.22 & 424 & 64.2 & {$[59.4,68.7]$} \\
$30-100$ & -0.15 & -0.19 & 1.09 & 632 & 57.6 & {$[53.6,61.5]$} \\
$100+$ & 0.02 & -0.09 & 1.40 & 2330 & 49.1 & {$[47.0,51.1]$} \\
\hline
\end{tabular}

with our finding that between 1951-1975 and 1976-2000, the odds of a negative DO trend occurring increased significantly.

Interdecadal changes in ocean ventilation can be caused by large scale changes in atmospheric and oceanic circulation patterns associated with the North Atlantic Oscillation (Johnson and Gruber, 2007), the Arctic Oscillation (Cui and Senjyu, 2010), the Pacific Decadal Oscillation (Frölisher et al., 2009) or the Southern Annular Mode (Verdy et al., 2007). The El Niño Southern Oscillation can also drive changes in oxygen on two to eight years time scales (Gutiérrez et al., 2008; Verdy et al., 2007). Given such variability on interannual to decadal and centennial time scales, the comparison of repeat hydrographic sections collected several years apart could lead to erroneous conclusions regarding basin-scale $\mathrm{O}_{2}$ content trends. Continuous, globally distributed in-situ oxygen measurements are required, such as those proposed on Argo profiling floats (Körtzinger et al., 2005; Gruber et al., 2010).

The importance of decadal variality is depicted for a few individual time series on Fig. 2, and is largely responsible for the different patterns of oxygen trends obtained for different time period lengths around Japan and Europe (Figs. 7 and 8 ). The color scales appearing next to each subplot in Figs. 7 and 8 clearly indicate that for shorter time periods, we tend to see oxygen trends of greater amplitude, either positive or negative. We further illustrate this by presenting the probability density functions of oxygen concentration trends determined by generating one million synthetic oxygen time series with length equal to 10 years, 25 years and 50 years respectively, assuming random white noise. For the simulations, we arbitrarily picked the median standard deviation of the annually-averaged oxygen time series listed in Table 2 , equal to $23 \mu \mathrm{mol} \mathrm{L}^{-1}$. The probability density functions of trends depicted on Fig. 9 highlight the fact that as time series become progressively shorter, the likelihood of seeing trends with large amplitudes increases. Conversely, as time series become longer, the likelihood of seeing large amplitude trends decreases. 


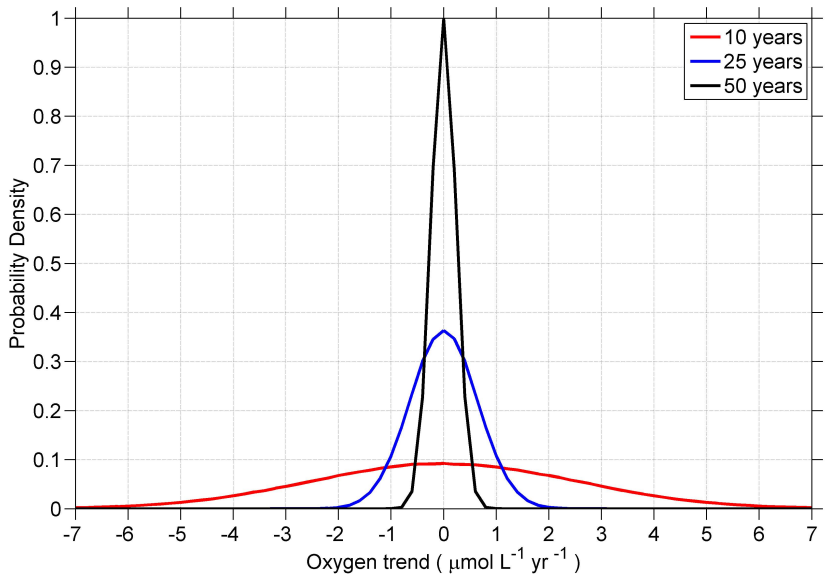

Fig. 9. Probability density diagram of oxygen concentration trends obtained from one million synthetic oxygen time series with length equal to 10 years (red), 25 years (blue) and 50 years (black), assuming random white noise with an interannual standard deviation of $23 \mu \mathrm{mol} \mathrm{L}{ }^{-1}$, the median standard deviation of the oxygen time series listed in Table 2.

\section{Conclusions}

In this study, we took a cursory look at oxygen trends in the global ocean. We compiled oxygen trend statistics based on published papers. We also calculated oxygen trends from the global ocean using all available oxygen data from public databases. The results from our analyses lead to the following conclusions.

- For the 1976-2000 period, oxygen concentrations were declining faster in the coastal ocean (median trend of $-0.28 \mu \mathrm{mol} \mathrm{L}^{-1} \mathrm{yr}^{-1}$ ) than in the open ocean (median trend of $0.02 \mu \mathrm{mol} \mathrm{L}^{-1} \mathrm{yr}^{-1}$ ) between 0 and $300 \mathrm{~m}$ depth.

- The percentage of negative oxygen trends is significantly greater in the coastal ocean $(64.2 \%)$ than in the open ocean $(49.1 \%)$.

- The odds of finding negative oxygen trends increased from the 1951-1975 period to the 1976-2000 period, indicating a recent worsening of hypoxia.

- In the open ocean ( $>100 \mathrm{~km}$ from shoreline), a significant difference between median published oxygen trends and median trends calculated from raw oxygen data suggests the existence of a publication bias in favor of negative trends.

The fact that oxygen declines are detected at the surface and at depth (Tables 5 to 7) is interesting. In the coastal band, based on the eutrophication hypothesis, we would have expected to see larger rates of oxygen decrease at depths of 20 to $50 \mathrm{~m}$ than at the surface, but we do not (Table 5). An alternative explanation might be that physical changes such as upper ocean warming (e.g., Levitus et al., 2009) may cause changes in oxygen solubility and in subsurface ventilation that are the main drivers of the observed oxygen changes in the coastal ocean. Future studies presenting the data in terms of percent solubility or apparent oxygen utilization (AOU) would be informative, as they may allow to isolate the effects of ocean physics from biology.

Acknowledgements. We thank Guillaume Hardy who imported oxygen data from the public databases into Matlab and wrote programs for statistical analysis and mapping. Benoît Roberge and Audrey Guérard digitized the oxygen time series from refereed journal publications. Christine Lemay helped us construct literature search equations in ASFA and SCOPUS. We are indebted to the thousands of scientists who made oxygen measurements and sent their data to public national and international data archive centers. We are also grateful to the two anonymous reviewers for making constructive suggestions that greatly improved the paper. This research was initiated as part of the activities of SCOR (Scientific Committee on Oceanic Research) Working Group 128 on "Natural and human-induced hypoxia and consequences for coastal areas", and was funded by the Climate Change Science Initiative of the Department of Fisheries and Oceans Canada.

Edited by: J. Middelburg

\section{References}

Aure, J. and Dahl, E.: Oxygen, nutrients, carbon and water exchange in the Skagerrak Basin, Cont. Shelf Res., 14, 965-977, 1994.

Blindheim, J. and Rey, F.: Water-mass formation and distribution in the Nordic Seas during the 1990s, ICES J. Mar. Sci., 61, 846863, 2004.

Bograd, S. J., Castro, C. G., Di Lorenzo, E., Palacios, D. M., Bailey, H., Gilly, W., and Chavez, F. P.: Oxygen declines and the shoaling of the hypoxic boundary in the California Current, Geophys. Res. Lett., 35, L12607, doi:10.1029/2008GL034185, 2008.

Bopp, L., Le Quéré, C., Heimann, M., Manning, A. C., and Monfray, P.: Climate-induced oceanic oxygen fluxes: Implications for the contemporary carbon budget, Global Biogeochem. Cy., 16, 6-1, 2002.

Carpenter, J. H.: The Chesapeake Bay Institute technique for the Winkler dissolved oxygen method, Limnol. Oceanogr., 10, 141143, 1965.

Chelton, D. B., Deszoeke, R. A., Schlax, M. G., El Naggar, K., and Siwertz, N.: Geographical variability of the first baroclinic Rossby radius of deformation, J. Phys. Oceanogr., 28, 433-460, 1998.

Conley, D. J., Carstensen, J., Aertebjerg, G., Christensen, P. B., Dalsgaard, T., Hansen, J. L. S., and Josefson, A. B.: Long-term changes and impacts of hypoxia in Danish coastal waters, Ecol. Appl., 17, S165-S184, 2007.

Cronin, T. M. and Vann, C. D.: The sedimentary record of climatic and anthropogenic influence on the Patuxent estuary and Chesapeake Bay ecosystems, Estuaries, 26, 196-209, 2003.

Cui, Y. and Senjyu, T.: Interdecadal oscillations in the Japan Sea Proper Water related to the Arctic Oscillation, J. Oceanogr., 66, 337-348, 2010. 
Díaz, R. and Rosenberg, R.: Spreading dead zones and consequences for marine ecosystems, Science, 321, 926-929, doi:10.1126/science.1156401, 2008.

Fagan, T.: Exact $95 \%$ confidence intervals for differences in binomial proportions, Computers in biology and medicine, 29, 8387, doi:10.1016/S0010-4825(98)00047-X, 1999.

Fonselius, S. and Valderrama, J.: One hundred years of hydrographic measurements in the Baltic Sea, J. Sea Res., 49, 229241, doi:10.1016/S1385-1101(03)00035-2, 2003.

Frölisher, T., Joos, F., Plattner, G.-K., Steinacher, M., and Doney, S. C.: Natural variability and anthropogenic trends in oceanic oxygen in a coupled carbon cycle-climate model ensemble, Global Biogeochem. Cy., 23, GB1003, doi:10.1029/2008GB003316, 2009.

Garcia, H. E. and Gordon, L. I.: Oxygen solubility in seawater: Better fitting equations, Limnol. Oceanogr., 37, 1307-1312, 1992.

Garcia, H. E., Boyer, T. P., Levitus, S., Locarnini, R. A., and Antonov, J.: On the variability of dissolved oxygen and apparent oxygen utilization content for the upper world ocean: 1955 to 1998, Geophys. Res. Lett., 32, L09604, doi:10.1029/2004GL022286, 2005.

Garcia, H. E., Locarnini, R. A., Boyer, T. P., and Antonov, J. I.: World Ocean Atlas 2005: Dissolved oxygen, apparent oxygen utilization, and oxygen saturation, Vol. 3 of NOAA Atlas NESDIS 63, US Government Printing Office, Washington, DC, 2006.

Gilbert, D., Sundby, B., Gobeil, C., Mucci, A., and Tremblay, G.H.: A seventy-two-year record of diminishing deep-water oxygen in the St. Lawrence estuary: The northwest Atlantic connection, Limnol. Oceanogr., 50, 1654-1666, 2005.

Gill, A. E.: Atmosphere-ocean dynamics, vol. 30 of International geophysics series, Academic Press, New York, USA, 1982.

Gruber, N., Doney, S. C., Emerson, S. R., Gilbert, D., Kobayashi, T., Körtzinger, A., Johnson, G. C., Johnson, K. S., Riser, S. C., and Ulloa, O.: Adding oxygen to Argo: Developing a global insitu observatory for ocean deoxygenation and biogeochemistry, Proceedings of OceanObs09: Sustained Ocean Observations and Information for Society, 21-25 September 2009, Hall, J., Harrison, D. E., and Stammer, D., ESA Publication WPP-306, Venice, Italy, 10 p., 2010.

Gutiérrez, D., Enríquez, E., Purca, S., Quipúzcoa, L., Marquina, R., Flores, G., and Graco, M.: Oxygenation episodes on the continental shelf of central Peru: Remote forcing and benthic ecosystem response, Prog. Oceanogr., 79, 177-189, doi:10.1016/j.pocean.2008.10.025, 2008.

Johnson, G. C. and Gruber, N.: Decadal water mass variations along $20^{\circ} \mathrm{W}$ in the northeastern Atlantic Ocean, Prog. Oceanogr., 73, 277-295, 2007.

Jones, E., Zemlyak, F., and Stewart, P.: Operating manual for the Bedford Institute of Oceanography automated dissolved oxygen titration system, Can. Tech. Rep. Hydrogr. Ocean Sci., 138, iv+51p., 1992.

Justić, D., Legović, T., and Rottini-Sandrini, L.: Trends in oxygen content 1911-1984 and occurrence of benthic mortality in the northern Adriatic Sea, Estuar. Coast. Shelf S., 25, 435-445, 1987.

Kang, D., Kim, J., Lee, T., and Kim, K.: Will the East/Japan Sea become an anoxic sea in the next century?, Mar. Chem., 91, 7784, 2004.
Kasai, A., Yamada, T., and Takeda, H.: Flow structure and hypoxia in Hiuchi-nada, Seto Inland Sea, Japan, Estuar. Coast. Shelf Sci., 71, 210-217, 2007.

Keeling, R. F. and Garcia, H. E.: The change in oceanic $\mathrm{O}_{2}$ inventory associated with recent global warming, P. Natl. Acad. Sci. USA, 99(12), 7848-7853, doi:10.1073/pnas.122154899, 2002.

Keeling, R. F., Koertzinger, A., and Gruber, N.: Ocean deoxygenation in a warming world, Ann. Rev. Mar. Sci., 2, 199-229, doi:10.1146/annurev.marine.010908.163855, 2010.

Kemp, W. M., Boynton, W. R., Adolf, J. E., Boesch, D. F., Boicourt, W. C., Brush, G., Cornwell, J. C., Fisher, T. R., Glibert, P. M., Hagy, J. D., Harding, L. W., Houde, E. D., Kimmel, D. G., Miller, W. D., Newell, R. I. E., Roman, M. R., Smith, E. M., and Stevenson, J. C.: Eutrophication of Chesapeake Bay: historical trends and ecological interactions, Mar. Ecol.-Prog. Ser., 303, 1-29, doi:10.3354/meps303001, 2005.

Konovalov, S. K. and Murray, J. W.: Variations in the chemistry of the Black Sea on a time scale of decades (1960-1995), J. Mar. Syst., 31, 217-243, 2001.

Körtzinger, A., Schimanski, J., and Send, U.: High quality oxygen measurements from profiling floats: a promising new technique, J. Atmos. Ocean. Tech., 22, 302-308, 2005.

Laine, A. O., Sandler, H., Andersin, A.-B., and Stigzelius, J.: Longterm changes of macrozoobenthos in the Eastern Gotland Basin and the Gulf of Finland (Baltic Sea) in relation to the hydrographical regime, J. Sea Res., 38, 135-159, 1997.

Laine, A. O., Andersin, A.-B., Leiniö, S., and Zuur, A. F.: Stratification-induced hypoxia as a structuring factor of macrozoobenthos in the open Gulf of Finland (Baltic Sea), J. Sea Res., 57, 65-77, doi:10.1016/j.seares.2006.08.003, 2007.

Levitus, S., Antonov, J. I., Boyer, T. P., Locarnini, R. A., Garcia, H. E., and Mishonov, A. V.: Global ocean heat content 19552008 in light of recently revealed instrumentation problems, Geophys. Res. Lett., 36, L07608, doi:10.1029/2008GL037155, 2009.

Lin, C., Ning, X., Su, J., Lin, Y., and Xu, B.: Environmental changes and the responses of the ecosystems of the Yellow Sea during 1976-2000, J. Mar. Syst., 55, 223-234, 2005.

Lysiak-Pastuszak, E., Drgas, N., and Piatkowska, Z.: Eutrophication in the Polish coastal zone: The past, present status and future scenarios, Mar. Pollut. Bull., 49, 186-195, doi:10.1016/j.marpolbul.2004.02.007, 2004.

Matear, R. J., Hirst, A. C., and McNeil, B. I.: Changes in dissolved oxygen in the Southern Ocean with climate change, Geochem. Geophy. Geosy., 1, Paper number 2000GC000086, 2000.

Minami, H., Kano, Y., and Ocawa, K.: Long-term variations of potential temperature and dissolved oxygen of the Japan Sea Proper Water, J. Oceanogr., 55, 197-205, 1999.

Monteiro, P. M. S., Van Der Plas, A., Mohrholz, V., Mabille, E., Pascall, A., and Joubert, W.: Variability of natural hypoxia and methane in a coastal upwelling system: Oceanic physics or shelf biology?, Geophys. Res. Lett., 33, L16614, doi:10.1029/2006GL026234, 2006.

Monteiro, P. M. S., van der Plas, A. K., Mélice, J.-L., and Florenchie, P.: Interannual hypoxia variability in a coastal upwelling system: Ocean-shelf exchange, climate and ecosystem-state implications, Deep-Sea Res. Pt. I, 55, 435-450, doi:10.1016/j.dsr.2007.12.010, 2008. 
Müller-Karger, F., Varela, R., Thunell, R., Scranton, M., Bohrer, R., Taylor, G., Capelo, J., Astor, Y., Tappa, E., Ho, T., and Walsh, J. J.: Annual cycle of primary production in the Cariaco Basin: Response to upwelling and implications for vertical export, J. Geophys. Res.-Oceans, 106, 4527-4542, 2001.

Nakanowatari, T., Ohshima, K. I., and Wakatsuchi, M.: Warming and oxygen decrease of intermediate water in the northwestern North Pacific, originating from the Sea of Okhotsk, 1955-2004, Geophys. Res. Lett., 34, L04602, doi:10.1029/2006GL028243, 2007.

Nixon, S. W.: Coastal marine eutrophication: a definition, social causes and future concerns, Ophelia, 41, 199-219, 1995.

Nordberg, K., Gustafsson, M., and Krantz, A.: Decreasing oxygen concentrations in the Gullmar Fjord, Sweden, as confirmed by benthic foraminifera, and the possible association with NAO, J. Mar. Syst., 23, 303-316, 2000.

Peng, S., Dai, M., Hu, Y., Bai, Z., and Zhou, R.: Long-term (19962006) variation of nitrogen and phosphorus and their spatial distributions in Tianjin coastal seawater, Bull. Environ. Contam. Tox., 83, 416-421, doi:10.1007/s00128-009-9680-1, 2009.

Petrie, B. and Yeats, P.: Annual and interannual variability of nutrients and their estimated fluxes in the Scotian Shelf - Gulf of Maine region, Can. J. Fish. Aquat. Sci., 57, 2536-2546, 2000.

Pitkänen, H., Lehtoranta, J., and Räike, A.: Internal nutrient fluxes counteract decreases in external load: The case of the estuarial eastern Gulf of Finland, Baltic Sea, Ambio, 30, 195-201, 2001.

Pohl, C. and Hennings, U.: The coupling of long-term trace metal trends to internal trace metal fluxes at the oxic-anoxic interface in the Gotland Basin $(5719,20 \mathrm{~N} ; 2003,00 \mathrm{E})$ Baltic Sea, J. Mar. Syst., 56, 207-225, doi:10.1016/j.jmarsys.2004.10.001, 2005.

Rabalais, N. N., Turner, R. E., and Wiseman Jr., W. J.: Gulf of Mexico hypoxia, a.k.a. "The dead zone", Ann. Rev. Ecol. Syst., 33, 235-263, doi:10.1146/annurev.ecolsys.33.010802.150513, 2002.

Rabalais, N. N., Turner, R. E., Sen Gupta, B. K., Boesch, D. F., Chapman, P., and Murrell, M. C.: Hypoxia in the northern Gulf of Mexico: Does the science support the plan to reduce, mitigate, and control hypoxia?, Estuaries Coasts, 30, 753-772, 2007.

Rosenberg, R.: Negative oxygen trends in Swedish coastal bottom waters, Mar. Pollut. Bull., 21, 335-339, 1990.

Sarmiento, J. L., Hughes, T. M. C., Stouffer, R. J., and Manabe, S.: Simulated response of the ocean carbon cycle to anthropogenic climate warming, Nature, 393, 245-249, 1998.

Stramma, L., Johnson, G. C., Sprintall, J., and Mohrholz, V.: Expanding oxygen-minimum zones in the tropical oceans, Science, 320, 655-658, doi:10.1126/science.1153847, 2008.

Stramma, L., Schmidtko, S., Levin, L. A., and Johnson, G. C.: Ocean oxygen minima expansions and their biological impacts, Deep-Sea Res., 57, 587-595, doi:10.1016/j.dsr.2010.01.005, 2010.
Swanson, R. L. and Parker, C. A.: Physical environmental factors contributing to recurring hypoxia in the New York Bight, T. Am. Fish. Soc., 117, 37-47, 1988.

Turner, R. E., Rabalais, N. N., Swenson, E. M., Kasprzak, M., and Romaire, T.: Summer hypoxia in the northern Gulf of Mexico and its prediction from 1978 to 1995, Mar. Environ. Res., 59, 65-77, 2005.

Tyler, R. M., Brady, D. C., and Targett, T. E.: Temporal and spatial dynamics of diel-cycling hypoxia in estuarine tributaries, Estuaries Coasts, 32, 123-145, doi:10.1007/s12237-008-9108-x, 2009.

Verdy, A., Dutkiewicz, S., Follows, M. J., Marshall, J., and Czaja, A.: Carbon dioxide and oxygen fluxes in the Southern Ocean: Mechanisms of interannual variability, Global Biogeochemical Cy., 21, GB2020, doi:10.1029/2006GB002916, 2007.

Weichart, G., Heise, G., and Becker, G. A.: A new concept for the assessment of the oxygen situation in a shelf sea area, Dt. Hydrogr. Z., 46, 263-275, 1994.

Wessel, P. and Smith, W. H. F.: A global self-consistent, hierarchical, high-resolution shoreline database, J. Geophys. Res.-Sol. Ea., 101, 8741-8743, 1996.

Whitney, F. A., Freeland, H. J., and Robert, M.: Persistently declining oxygen levels in the interior waters of the eastern subarctic Pacific, Prog. Oceanogr., 75, 179-199, 2007.

Wilson, R. E., Swanson, R. L., and Crowley, H. A.: Perspectives on long-term variations in hypoxic conditions in western Long Island Sound, J. Geophys. Res.-Oceans, 113, C12011, doi:10.1029/2007JC004693, 2008.

Winkler, L.: Die Bestimmung des im Wasser gelsten Sauerstoffen, Ber. Dtsch. Chem. Ges., 21, 2843-2855, 1888.

Wong, G. T. F. and Li, K.-Y.: Winkler's method overestimates dissolved oxygen in seawater: Iodate interference and its oceanographic implications, Mar. Chem., 115, 86-91, doi:10.1016/j.marchem.2009.06.008, 2009.

Yakushev, E. V., Chasovnikov, V. K., Debolskaya, E. I., Egorov, A. V., Makkaveev, P. N., Pakhomova, S. V., Podymov, O. I., and Yakubenko, V. G.: The northeastern Black Sea redox zone: Hydrochemical structure and its temporal variability, Deep-Sea Res. Pt. II, 53, 1769-1786, 2006.

Yasuhara, M., Yamazaki, H., Tsujimoto, A., and Hirose, K.: The effect of long-term spatiotemporal variations in urbanizationinduced eutrophication on a benthic ecosystem, Osaka Bay, Japan, Limnol. Oceanogr., 52, 1633-1644, 2007.

Yunev, O. A., Carstensen, J., Moncheva, S., Khaliulin, A., Aertebjerg, G., and Nixon, S.: Nutrient and phytoplankton trends on the western Black Sea shelf in response to cultural eutrophication and climate changes, Estuar. Coast. Shelf S., 74, 63-76, 2007. 